\title{
Reduction in Serum Lecithin:Cholesterol Acyltransferase Activity Prior to the Occurrence of Ketosis and Milk Fever in Cows
}

\author{
Hisami NAKAGAWA-UETA ${ }^{1)}$ and Norio KATOH $^{2) *}$ \\ ${ }^{1)}$ Ishikawa Hokubu Hygiene Service Center, Tatsuruhama-cho, Ishikawa 929-2126 and ${ }^{2)}$ Hokkaido Research Station, National Institute of \\ Animal Health, 4 Hitsujigaoka, Sapporo 062-0045, Japan
}

(Received 23 June 2000/Accepted 12 August 2000)

ABSTRACT. Lecithin:cholesterol acyltransferase (LCAT) is the enzyme responsible for production of cholesteryl esters in plasma. The LCAT activity is reduced in cows with fatty liver developed during the nonlactating stage and those with the fatty liver-related postparturient diseases such as ketosis. The purpose of the present study was to examine whether reduced LCAT activity during the nonlactating stage could be detected before the occurrence of postparturient diseases. Sera from 24 cows were collected at approximately 10-day intervals from -48 to +14 days from parturition. Of the 24 cows, 14 were apparently healthy, whereas 7 had ketosis and 3 had milk fever at around parturition. Of the 14 healthy cows, 7 had unaltered LCAT activity during the observation period, whereas 7 showed reduced activity from -20 to +14 days. Ketosis and milk fever occurred at from -3 to +10 days, but reductions of LCAT activity in diseased cows had already been observed from days -20 to 0 . These results suggest that LCAT activity is virtually unaffected during the peripartum period at least in some healthy cows and also that the reduction in LCAT activity can be detected before the occurrence of ketosis and milk fever.

KEY WORDS: bovine, ketosis, lecithin:cholesterol acyltransferase, milk fever, parturition.

J. Vet. Med. Sci. 62(12): 1263-1267, 2000

Lecithin:cholesterol acyltransferase (LCAT, EC 2.3.1.43) is mainly synthesized by the liver and, in plasma, catalyzes the transesterification of free cholesterol (FC) with lecithin (phosphatidylcholine), and produces cholesteryl esters (CE) [2]. The enzyme is activated by apolipoprotein (apo) A-I that is mainly distributed in the high-density lipoprotein (HDL) fraction, and FC taken up by HDL from extrahepatic tissues serves as a substrate for LCAT. The produced CE is transferred to low-density lipoprotein (LDL), is taken up by the liver or steroidogenic tissues, and is converted to bile acids or steroid hormones.

Our previous report demonstrated that serum LCAT activity is reduced in cows with fatty liver experimentally induced by ethionine [8] and in spontaneous cases of cow fatty liver [4]. We have also demonstrated that LCAT activity is reduced in cows with ketosis and left displacement of the abomasum [5]. Postparturient metabolic diseases such as ketosis are known to be caused by fatty liver developed during the nonlactating stage $[1,3,7]$. Fatty infiltration of the liver due to excess uptake of nonesterified fatty acids (NEFA) from adipose tissues may impair the synthesis or secretion of LCAT. Although the mechanistic basis is unknown, disturbance of the reverse cholesterol transport from extrahepatic tissues to the liver, the major role of LCAT, is thought to be responsible for the development of the postparturient diseases.

During the peripartum period, concentrations of apoB-100 [10], the major apoprotein in very low-density lipoprotein and LDL fractions, and of apoC-III [9], mainly distributed in

\footnotetext{
* Correspondence to: Katoh, N., Hokkaido Research Station, National Institute of Animal Health, 4 Hitsujigaoka, Sapporo 062-0045, Japan.
}

the HDL fraction, are physiologically decreased. The decreases may be caused by suppressed liver function in association with the transition from the pregnant, nonlactating state to the nonpregnant, lactating state. In the case of LCAT activity, we have initially observed reduced activity during the period [8]. However, in another experiment [5], the reduction was not as distinct as in the previous study. If LCAT activity is practically unaltered during the peripartum period in healthy cows, LCAT activity during the nonlactating stage can be used as a marker for cows with fatty liver, and in turn for cows susceptible to fatty liver-related postparturient diseases. The purpose of the present study was to examine whether LCAT activity in healthy cows is reduced during the peripartum period and, moreover, whether a reduction in LCAT activity is detected before the occurrence of ketosis and milk fever.

\section{MATERIALS AND METHODS}

Cows: Holstein cows ( $\mathrm{n}=24,2$ to 7 years old) during the peripartum period ( -48 to +14 days from parturition) in farms of Ishikawa Prefecture were used. Their milk yields were approximately $8,000 \mathrm{~kg}$ per year per cow, and their diet was as described previously [4]. Sera were collected at approximately 10-day intervals during the peripartum period. Of the cows, 14 had no apparent clinical signs during the observed period, whereas 7 had ketosis at -2 to +9 days and 3 cows had milk fever at -3 to +10 days. One cow developed ketosis at 5 days after parturition and suffered from left displacement of the abomasum at 7 days. Cows with ketosis were detected by clinical signs and urine ketone reaction [6]. Cows characterized by sternal recumbency and by quick standing in response to calcium treatment were considered to have milk 
fever. Blood samples were taken in the morning (before feeding).

LCAT activity: The LCAT activity was determined with a commercial kit (Dai-ichi Pure Chemicals, Tokyo, Japan) by estimating the concentration of FC as described previously $[4,5,8]$. Briefly, $100 \mu \mathrm{l}$ of serum (stored at $-20^{\circ} \mathrm{C}$ and used within 2 months) was incubated at $37^{\circ} \mathrm{C}$ for $40 \mathrm{~min}$, which was within the linear phase of the time course. The unit of LCAT activity (U) was the decrease in nmol of FC per hour per $\mathrm{m} l$ of serum.

Other methods: Serum concentrations of triglycerides (TG), total cholesterol, FC, phospholipids (PL) and NEFA, calcium, and activity of aspartate aminotransferase (AST) were measured by use of kits (Wako Pure Chemicals, Osaka, Japan). The CE concentration was calculated by subtracting the FC concentration from that of total cholesterol. Urine ketone was detected using a kit from Fujisawa Pharmaceutical Co. (Osaka, Japan). The apoB-100 concentration was determined as described previously [10]. Immunoblot analysis was performed $[9,10]$. Each assay was done in duplicate. The data were analyzed, using one-way ANOVA and Scheffe's F-test. Values are expressed as mean \pm SD.

\section{RESULTS}

Of the 24 cows monitored, 14 were apparently healthy and did not show distinct signs of diseases during the peripartum period. LCAT activities in the 14 healthy cows during a period of -48 to -21 days from parturition (Table 1) were similar to the reported values of healthy cows $[4,5,8]$. From -20 to +14 days, LCAT activities of the 14 healthy cows showed individual variations. The 14 healthy cows were allocated into two groups on the basis of LCAT activity, healthy group $1(n=7)$ and healthy group $2(n=7)$. The borderline value for the two groups was obtained from the mean - 2SD value for the LCAT activity in the 24 cows during the period of -48 to -21 days $(890 \pm 74 \mathrm{U})$, and was calculated to be $742 \mathrm{U}$. In healthy group 1, LCAT activity was always higher than the borderline value during periods of -20 to -11 days, -10 to 0 days and +1 to +14 days, whereas in healthy group 2, the activity was occasionally or continually lower than the borderline value. When compared with the period of -48 to -21 days, LCAT activities in healthy group 1 were slightly, but not significantly, reduced during the periods of -10 to 0 days and +1 to +14 days. By comparison, the activities during periods of -10 to 0 days and +1 to +14 days in healthy group 2 were significantly lower than the value during the period of -48 to -21 days of the same group. The reduction during -20 to -11 days did not reach statistical significance $(P=0.237)$. Comparing the corresponding periods of the two groups, the activities during periods of -20 to -11 days, -10 to 0 days and +1 to +14 days were lower in healthy group 2 than in healthy group 1 .

No significant difference was observed in the FC concentration within the four periods of each group or between the corresponding periods of the two healthy groups. The CE concentrations during -20 to -11 days and +1 to +14 days in healthy group 2 were lower than those during the corresponding periods in healthy group 1 . The decrease during -10 to 0 days in healthy group 2 did not reach significance $(P=0.106)$. Concentrations of PL and TG were not different within the four periods of each group or between the corresponding periods of the two groups. The NEFA concentration and AST activity increased during +1 to +14 days in healthy group 2, compared with during -48 to -21 days in the same group. In healthy group 1 , the apoB-100 concentration decreased in the periods from -10 to 0 days and +1 to +14 days, compared with the value in the period from -48 to -21 days. A decreased apoB-100 concentration of a cow in healthy group 1 was also shown by immunoblot analysis (Fig. 1). The decreased apoB-100 concentrations during the periods from -10 to 0 days and +1 to +14 days were similarly observed in healthy group 2; the differences from the corresponding periods of healthy group 1 were not significant.

Changes observed in cows with ketosis were similar to those in healthy group 2, but the differences from healthy group 1 became more distinct. Compared with the period from -48 to -21 days, LCAT activity was reduced during the periods from -10 to 0 days and +1 to +14 days. The activities during the periods from -20 to -11 days, -10 to 0 days and +1 to +14 days were lower than those during the corresponding periods of healthy group 1 . The $\mathrm{CE}$ concentrations during the three periods $(-20$ to +14 days $)$ were lower than those in healthy group 1. Significant differences were further observed in PL, TG and NEFA concentrations. Elevated AST activity during the period from +1 to +14 days was not significant because of the large deviation. The apoB-100 concentrations during the periods from -10 to 0 days and +1 to +14 days were lower than the values of the corresponding periods of healthy group 1 . The decrease in the apoB-100 concentration of a cow with ketosis was reproduced by immunoblot analysis (Fig. 1). Urine ketone reaction was not detected before the onset of ketosis, as described previously [6].

Three cows had milk fever at $-3,0$ and 10 days from parturition, and their serum calcium concentrations at these days were in the range of 4.5 to $6.6 \mathrm{mg} / 100 \mathrm{ml}(5.6 \pm 1.1 \mathrm{mg} / 100$ $\mathrm{m} l$ ). Before the occurrence of milk fever, calcium concentrations in the 3 cows $(9.0 \pm 1.1 \mathrm{mg} / 100 \mathrm{ml})$ were similar to those in healthy group $1(9.3 \pm 0.8 \mathrm{mg} / 100 \mathrm{ml})$, healthy group $2(8.9 \pm 0.9 \mathrm{mg} / 100 \mathrm{~m} l)$, and cows with ketosis $(8.9 \pm 1.1 \mathrm{mg} /$ $100 \mathrm{ml}$ ). LCAT activities in cows with milk fever were reduced: $1,041 \pm 14 \mathrm{U}$ ( -48 to -21 days); $790 \pm 103 \mathrm{U}(-20$ to -11 days, $P<0.05$ compared with the value of the period from -48 to -21 days); $649 \pm 132 \mathrm{U}$ ( -10 to 0 days, $P<0.01$ ); and $678 \pm 209$ ( +1 to +14 days, $P<0.05)$. The CE concentrations were also decreased: $101 \pm 16.0 \mathrm{mg} / 100 \mathrm{ml}(-48$ to -21 days); $69.4 \pm 9.1$ ( -20 to -11 days, $P<0.05) ; 51.9 \pm 12.3(-10$ to 0 days, $P<0.01$ ); and $57.5 \pm 6.1$ ( +1 to +14 days, $P<0.01)$.

\section{DISCUSSION}

The present study indicated that LCAT activity was already reduced in cows with ketosis and milk fever before 
Table 1. Lipid and protein concentrations and enzyme activities during the peripartum period in healthy cows and cows with ketosis

\begin{tabular}{|c|c|c|c|c|c|c|c|c|}
\hline \multirow{2}{*}{$\begin{array}{l}\text { Group/ } \\
\text { Days } \\
\text { Healthy } 1\end{array}$} & \multirow[t]{2}{*}{ FC } & \multirow[t]{2}{*}{$\mathrm{CE}$} & \multirow[t]{2}{*}{ PL } & \multirow[t]{2}{*}{ TG } & \multicolumn{2}{|c|}{ NEFA ApoB-100 } & \multirow[t]{2}{*}{ AST } & \multirow[t]{2}{*}{ LCAT } \\
\hline & & & & & & & & \\
\hline$-48--21$ & $\begin{array}{c}27.3 \pm \\
13.4\end{array}$ & $\begin{array}{c}114 \pm \\
40.2\end{array}$ & $\begin{array}{c}130 \pm \\
43.5\end{array}$ & $\begin{array}{c}17.0 \pm \\
6.5\end{array}$ & $\begin{array}{c}146 \pm \\
104\end{array}$ & $\begin{array}{c}447 \pm \\
93\end{array}$ & $\begin{array}{c}55.4 \pm \\
25.4\end{array}$ & $\begin{array}{c}932 \pm \\
59\end{array}$ \\
\hline$-20--11$ & $\begin{array}{c}27.1 \pm \\
12.5\end{array}$ & $\begin{array}{c}120 \pm \\
29.9\end{array}$ & $\begin{array}{c}153 \pm \\
41.6\end{array}$ & $\begin{array}{c}15.8 \pm \\
7.8\end{array}$ & $\begin{array}{c}89 \pm \\
61\end{array}$ & $\begin{array}{c}309 \pm \\
88\end{array}$ & $\begin{array}{c}55.3 \pm \\
13.4\end{array}$ & $\begin{array}{c}939 \pm \\
30\end{array}$ \\
\hline$-10-0$ & $23.9 \pm$ & $89.4 \pm$ & $126 \pm$ & $16.5 \pm$ & $187 \pm$ & $264 \pm$ & $55.9 \pm$ & $858 \pm$ \\
\hline$+1-+14$ & $\begin{array}{c}7.1 \\
23.5 \pm\end{array}$ & $\begin{array}{c}28.1 \\
85.7 \pm\end{array}$ & $\begin{array}{r}23.3 \\
123 \pm\end{array}$ & $\begin{array}{c}5.9 \\
10.8 \pm\end{array}$ & $\begin{array}{c}264 \\
295 \pm\end{array}$ & $\begin{array}{c}83^{\S} \\
226 \pm\end{array}$ & $\begin{array}{c}7.6 \\
82.6 \pm\end{array}$ & $\begin{array}{c}56 \\
897 \pm\end{array}$ \\
\hline & 3.3 & 16.6 & 22.0 & 4.2 & 254 & $65^{\S}$ & 23.8 & 67 \\
\hline Healthy 2 & & & & & & & & \\
\hline$-48--21$ & $\begin{array}{c}22.0 \pm \\
3.9\end{array}$ & $\begin{array}{c}81.7 \pm \\
15.6\end{array}$ & $\begin{array}{c}124 \pm \\
10.1\end{array}$ & $\begin{array}{c}16.2 \pm \\
6.4\end{array}$ & $\begin{array}{c}167 \pm \\
150\end{array}$ & $\begin{array}{c}356 \pm \\
106\end{array}$ & $\begin{array}{c}53.4 \pm \\
8.0\end{array}$ & $\begin{array}{c}860 \pm \\
37\end{array}$ \\
\hline$-20--11$ & $\begin{array}{c}18.0 \pm \\
4.9\end{array}$ & $\begin{array}{l}61.6 \pm \\
13.8^{* *}\end{array}$ & $\begin{array}{c}102 \pm \\
11.5\end{array}$ & $\begin{array}{c}18.8 \pm \\
5.6\end{array}$ & $\begin{array}{c}60 \pm \\
19\end{array}$ & $\begin{array}{c}292 \pm \\
67\end{array}$ & $\begin{array}{c}55.2 \pm \\
9.3\end{array}$ & $\begin{array}{l}703 \pm \\
77 * *\end{array}$ \\
\hline$-10-0$ & $16.4 \pm$ & $66.3 \pm$ & $103 \pm$ & $13.9 \pm$ & $271 \pm$ & $189 \pm$ & $62.1 \pm$ & $636 \pm$ \\
\hline$+1-+14$ & $\begin{array}{c}5.5 \\
15.8 \pm \\
4.0\end{array}$ & $\begin{array}{c}16.9 \\
60.2 \pm \\
14.5^{*}\end{array}$ & $\begin{array}{c}16.4 \\
106 \pm \\
19.7\end{array}$ & $\begin{array}{c}5.5 \\
7.7 \pm \\
4.9\end{array}$ & $\begin{array}{c}68 \\
527 \pm \\
232^{\dagger}\end{array}$ & $\begin{array}{c}68^{\dagger} \\
162 \pm \\
54^{\S}\end{array}$ & $\begin{array}{c}21.2 \\
90.4 \pm \\
28.0^{\dagger}\end{array}$ & $\begin{array}{c}127^{\dagger *} \\
658 \pm \\
145^{\S * *}\end{array}$ \\
\hline Ketosis & & & & & & & & \\
\hline$-48--21$ & $\begin{array}{c}18.6 \pm \\
8.5\end{array}$ & $\begin{array}{c}68.8 \pm \\
13.2\end{array}$ & $\begin{array}{c}108 \pm \\
16.5\end{array}$ & $\begin{array}{c}24.2 \pm \\
7.4\end{array}$ & $\begin{array}{c}103 \pm \\
89\end{array}$ & $\begin{array}{c}364 \pm \\
47\end{array}$ & $\begin{array}{c}44.2 \pm \\
6.1\end{array}$ & $\begin{array}{c}874 \pm \\
107\end{array}$ \\
\hline$-20--11$ & $\begin{array}{c}19.6 \pm \\
5.1\end{array}$ & $\begin{array}{l}67.6 \pm \\
13.2 * *\end{array}$ & $\begin{array}{r}99.8 \pm \\
17.8^{*}\end{array}$ & $\begin{array}{c}21.2 \pm \\
8.5\end{array}$ & $\begin{array}{c}96 \pm \\
54\end{array}$ & $\begin{array}{c}341 \pm \\
102\end{array}$ & $\begin{array}{c}47.2 \pm \\
8.8\end{array}$ & $\begin{array}{c}778 \pm \\
91^{*}\end{array}$ \\
\hline$-10-0$ & $19.1 \pm$ & $51.4 \pm$ & $85.0 \pm$ & $15.9 \pm$ & $448 \pm$ & $129 \pm$ & $49.9 \pm$ & $623 \pm$ \\
\hline & 9.4 & $16.2 * *$ & 27.7 & 6.9 & 430 & $61^{\S *}$ & 10.6 & $119^{\S * *}$ \\
\hline$+1-+14$ & $\begin{array}{c}17.9 \pm \\
4.4\end{array}$ & $\begin{array}{l}53.3 \pm \\
18.2 * *\end{array}$ & $\begin{array}{c}93.4 \pm \\
25.1\end{array}$ & $\begin{array}{c}8.0 \pm \\
5.7^{\S}\end{array}$ & $\begin{array}{c}733 \pm \\
534^{\dagger}\end{array}$ & $\begin{array}{c}113 \pm \\
61^{\S *}\end{array}$ & $\begin{array}{c}207 \pm \\
209\end{array}$ & $\begin{array}{c}599 \pm \\
143^{\S * *}\end{array}$ \\
\hline
\end{tabular}

Healthy cows were retrospectively allotted into two groups on the basis of LCAT activity, healthy group $1(n=7)$ and healthy group $2(n=7)$. Ketosis $(n=7)$ occurred at $-2,0,0,+1,+3,+5$ and +9 days from parturition. Sera at day 0 were collected before parturition. Sample numbers are 6 to 8 in each period of the three groups. ${ }^{\dagger}, P<0.05 ;{ }^{\S}, P<0.01$, compared with the respective values for the period of -48 to -21 days of the same groups. *, $P<0.05 ; * *, P<0.01$, compared with values during the corresponding periods of healthy group 1 . Units are $\mathrm{mg} / 100 \mathrm{~m} l$ for $\mathrm{FC}, \mathrm{CE}, \mathrm{PL}$ and TG, $\mu \mathrm{Eq} / \mathrm{L}$ for NEFA, $\mu \mathrm{g} / \mathrm{m} l$ for apoB- 100 , IU/ $\mathrm{L}$ for AST, and U for LCAT.

they occurred. In healthy controls, there were two types of cows; one had unaltered LCAT activity during the peripartum period (healthy group 1), whereas the other (healthy group 2) showed reduced activity compared with the value on and before day -21 from parturition. In addition to LCAT activity, concentrations of lipids, particularly CE, were decreased in healthy group 2 as well as in cows with ketosis.

The reduced LCAT activity in healthy group 2 appeared to be due to fatty liver, because in cows with fatty liver, LCAT activity is reduced $[4,8]$, and because the CE concentration, the product of the LCAT reaction, is also decreased in cows with fatty liver $[4,5]$. In addition to the LCAT activity and CE concentration, the patterns of increases in the NEFA concentration and AST activity in healthy group 2 were similar to those in cows with ketosis rather than to healthy group 1 . Postparturient diseases such as ketosis and milk fever are thought to be derived from fatty liver developed during the nonlactating stage $[1,3,7]$. It is conceivable that the cows in healthy group 2 had severe fatty liver, but did not suffer from the postparturient diseases at around parturition. To assess this hypothesis, an experimental study using liver samples for determination of hepatic TG contents is required. Liver biopsy of cows in farms is difficult, in particular during the peripartum period.

Other than the LCAT activity and CE concentration, the apoB-100 concentration was decreased in healthy group 2 and in cows with ketosis. We have previously shown that the apoB-100 concentration is decreased in cows with fatty liver, ketosis and left displacement of the abomasum [6]. However, unlike LCAT activity, the apoB-100 concentration is physiologically decreased during the peripartum period, although the decrease is not as large as in diseased cows [10]. The physiological decrease during the peripartum period was supported by the present finding that of a decrease in the apoB-100 concentration in healthy group 1 . The concentration of HDL apoC-III is also decreased in healthy cows dur- 


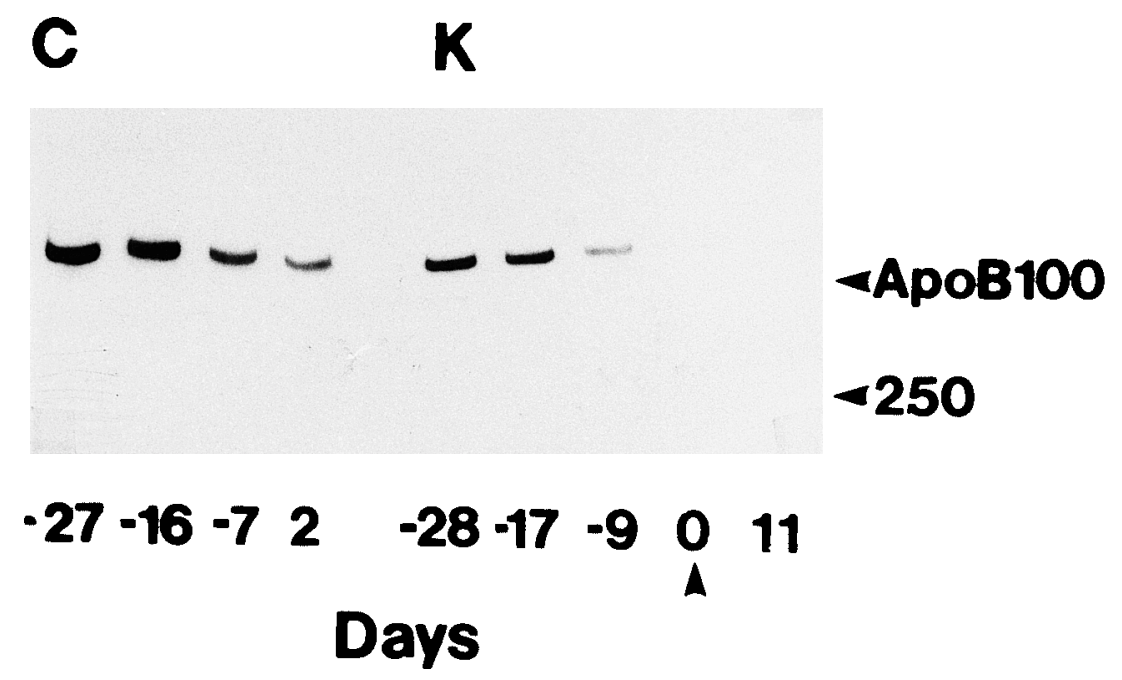

Fig. 1. Immunoblot analysis of apoB-100 in sera from a cow in healthy group 1 (C) and a cow with ketosis (K, occurred at day 0 from parturition as indicated by an arrowhead). Sera (10- $\mu l$ of 20-fold dilution with phosphate-buffered saline) were electrophoresed in a 5-20\% gradient gel in the presence of sodium dodecyl sulfate and 2-mercaptoethanol. After the transfer of proteins, the polyvinylidene difluoride membrane was incubated with rabbit anti-bovine apoB-100 serum and then with goat anti-rabbit IgG serum conjugated with horseradish peroxidase. A chemiluminescence reagent (ECL, Amersham Pharmacia Biotech, Chalfont, Buckinghamshire, UK) was used to detect apoB-100. The number 250 indicates the position of a $250 \mathrm{kDa}$ marker protein in molecular weight markers (Full Range Rainbow, Amersham Pharmacia Biotech). Relative densities were: 100 (day -27), 99 (day -16), 53 (day -7), 38 $($ day +2 ) in the healthy control; 63 (day -28), 56 (day -17), 23 (day -9), 2 (day 0) and 3 (day +11 ) in ketosis.

ing the peripartum period [9]. The discrepancy between apoC-III and LCAT appears to be explained by their different modes of secretion in that LCAT is functionally associated with HDL in plasma, but is secreted by the liver independent of HDL [2]. Constant hepatic synthesis and secretion of LCAT may be required to maintain the persistent rate of cholesterol esterification, because $\mathrm{CE}$ is used for the production of steroid hormones that are essential for the transition from the pregnant, nonlactating state to the nonpregnant, lactating state. As shown in Table 1, LCAT activity in healthy group 1 had small deviations (less than $10 \%$ of the mean values). The small individual difference in LCAT activity is beneficial it to the survey for extraordinary values. LCAT activity during the peripartum period is suggested to be the most useful marker for detection of cows susceptible to postparturient diseases such as ketosis. The decreased concentration of CE may be linked to the reduction in LCAT activity. The decreases in concentrations of FC and PL (both are the substrates for LCAT) were not as distinct as that of the CE concentration. Plasma FC and PL concentrations are regulated in a multiple manner; for example, uptake by the mammary gland or by HDL from extrahepatic tissues. The diagnostic values of the increases in the NEFA concentration and AST activity appeared to be low because of their large deviations.

The mechanistic basis for the reduction of LCAT activity before the occurrence of postparturient diseases is not known. Excess infiltration of NEFA from adipose tissue and resulting accumulation of hepatic TG may impair the synthesis and/or secretion of LCAT, and in turn reduce plasma LCAT activity. Because LCAT activities were not significantly different between healthy group 2 and cows with ketosis, a factor or factors other than LCAT activity may be directly responsible for the occurrence of postparturient diseases. The reduction of LCAT activity seems to be basically relevant to the development of postparturient diseases.

In conclusion, LCAT activity was unaltered during the peripartum period at least in some healthy cows. A reduction in LCAT activity was observed prior to the occurrence of ketosis and milk fever. LCAT activity during the peripartum period is suggested to be a useful marker for detection of cows susceptible to fatty liver-related postparturient diseases.

ACKNOWLEDGEMENT. We are grateful to Mr. M. K. Barrymore for his critical reading of the manuscript.

\section{REFERENCES}

1 Herdt, T. H. 1988. Fatty liver in dairy cows. Vet. Clin. North Am. Food Anim. Pract. 4: 269-287.

2. Jonas, A. 1998. Regulation of lecithin cholesterol acyltransferase activity. Prog. Lipid Res. 37: 209-234.

3. Morrow, D. A. 1976. Fat cow syndrome. J. Dairy Sci. 59: $1625-1629$.

4. Nakagawa, H., Oikawa, S., Oohashi, T. and Katoh, N. 1997. 
Decreased serum lecithin:cholesterol acyltransferase activity in spontaneous cases of fatty liver in cows. Vet. Res. Commun. 21: $1-8$.

5. Nakagawa, H. and Katoh, N. 1998. Reduced activity of lecithin:cholesterol acyltransferase in the serum of cows with ketosis and left displacement of the abomasum. Vet. Res. Commun. 22: $517-524$.

6. Oikawa, S., Katoh, N., Kawawa, F and Ono, Y. 1997. Decreased serum apolipoprotein B-100 and A-I concentrations in cows with ketosis and left displacement of the abomasum. Am. J. Vet. Res. 58: 121-125.

7. Reid, I. M. 1980. Incidence and severity of fatty liver in dairy cows. Vet. Rec. 107: 281-284.
8. Uchida, E., Katoh, N. and Takahashi, K. 1995. The activity of lecithin:cholesterol acyltransferase in the serum of cows at parturition or with fatty liver. Vet. Res. Commun. 19: 343-351.

9. Yamamoto, M., Katoh, N. and Oikawa, S. 1998. Evaluation of serum apolipoprotein C-III concentration by enzyme-linked immunosorbent assay and its higher concentration in cows during midlactation than during the nonlactating stage. Am. J. Vet. Res. 59: 1358-1363.

10. Yamamoto, O., Oikawa, S. and Katoh, N. 1995. Enzyme-linked immunosorbent assay for serum apolipoprotein B-100, a major triglyceride-transport protein in dairy cows. Am. J. Vet. Res. 56: 1413-1417. 